\title{
家庭における育粉かんへの害虫の侵入に関する調査
}

\author{
千種翠*.中田英吉*
}

\section{Studies on Invading Insects and Mites of Dry Milk Cans Set in Several Homes}

\section{Midori CHIGUSA and Eikichi NAKADA}

(Tokyo Metropolitan Research Laboratory of Public Health: 24-1, 3-chome, Hyakunin-cho, Shinjuku-ku, Tokyo)

\begin{abstract}
Insects and mites invading into four types of milk powder cans and changes of water content of their cans were investigated after setting them for two weeks in thirty homes which were five kitchens of apartment buildings, five of houses and five of stores (food-stores or restaurants) in both of the downtown and the suburbs. Four types milk powder cans were; 1) A can closed by a metal screw cap. 2) Closed by a polyethylenecap. 3) Ccovered loosely by a polyethylene-cap without being closed and fixed by vinyl tapes on both sides. 4) Closed by a cap of which one-fourth part was cut off. We tested in summer, autumn and late autumn in 1974.

It was found that water content of milk powder was highly correlative with the number of kinds of invading insects and mites. The numbers of insects and mites increased more in cans set in moist places. Also it was found that cans closed by polyethylenecaps were less invaded by insects and mites than cans closed by metal screw caps because the latter cans had more openings than the former.

There were no statistical significant differences between downtown and suburbs, among apartments, houses and stores, and among three tests done at three seasons.
\end{abstract}

現在，育粉工場内は非常に清橴に保たれているので，

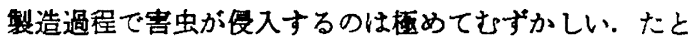
え曼入したとしても，育粉かん内は窒素ガスが充てんし てあるため，長期間生存しにくいと考えられている1). また，製品は製造してから販売されるまで半年間ぐらい かかるといわれているので，育粉かんに虫が入っていた といら苦徆の多くは，開かん後に害蚆入ったものと思 われる. 著者らは，開かん後のふたの閉め方やかんの監 き場所によって，虫の侵入状況がいか異なるかを知る ため，次のような調査を行い，興味ある結果を得たので 報告する.

\section{嘼查方法}

都心と都下の団地やアパート（高㬝住宅），一戸建住 宅, 商店 (食料品店, 飲食店) の 3 種類の家莛 30 軒を Table 1 の上うに選定し, 主にその台所の食器棚に充粉 かんを置いた，設置期間は，Table 2 のように 6 月から 11月にかけて，3回調查を行った，都心群と都下群では 1 週間ずつ, 調查の時期がずれている. $200 \mathrm{~g}$ 入育粉か

\footnotetext{
* 東京都立街生研究所：東京都新宿区百人町 3-24-1
}

んの育粉量を $1 / 4(50 \mathrm{~g})$ に隇らし, Fig. 1 に示すよう な 4 種類の育粉かん，すなわち，(1)金属製のねじ込みぶ

Table 1. Setting place of Milk Powder Cans

\begin{tabular}{l|c|c} 
& Downtown & Suburbs \\
\hline $\begin{array}{c}\text { Apartment } \\
\text { building }\end{array}$ & 5 Families & 5 Families \\
$\begin{array}{l}\text { House } \\
\text { Store* }\end{array}$ & $"$ & $"$
\end{tabular}

* food stores or restaurants.

Table 2. Periods of Setting Milk Powder Cans, 1974.

\begin{tabular}{|c|c|c|}
\hline & Downtown & Suburbs \\
\hline First test & $\begin{array}{l}\text { 25th, June } \\
\sim 9 \text { th, July }\end{array}$ & $\begin{array}{l}\text { 2nd, July } \\
\sim 16 \text { th, July }\end{array}$ \\
\hline Second test & $\begin{array}{l}\text { 10th, Sept. } \\
\sim 24 \text { th, Sept. }\end{array}$ & $\begin{array}{l}\text { 18th, Sept. } \\
\sim \text { 2nd, Oct. }\end{array}$ \\
\hline Third test & $\begin{array}{l}\text { 22nd, Oct. } \\
\sim 5 \text { th, Nov. }\end{array}$ & $\begin{array}{l}\text { 29th, Oct. } \\
\sim 12 \text { th, Nov. }\end{array}$ \\
\hline
\end{tabular}



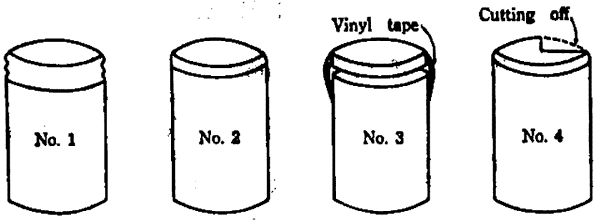

Fig. 1. How to set milk powder cans.

No. 1: Can was Closed by a metal screw cap.

No. 2: Can was closed by a polyethylene cap.

No. 3: Can was loosely covered by a polyethylene-cap without being closed and fixed by vinyl tapes on both sides.

No. 4: Can was closed by a cap of which onefourth part was cut off.

たで密閉したもの，(2)゙リェチレン嫳のふたで密閉した もの，(3)ボリエチレン製のふたを简単にから゙せて 2 か所 ビニルテーブで止めたもの（以下，ふたのせかんとい ら)、および(4) $1 / 4$ 切り取ったボリエチレンふたをきちん と閉めたもの（以下，1/4 あけかんといら）を作り， Fig. 2のよ5に，2週间固いた．設置場所までの運搬 の途中で害虫が侵入するのを防ぐために，4 種類のかん を密閉した後（1/4 あけかんは，替ぶたを使用した）， さらに，ビニルテーブで完閉し，回収時の運搬も同じ方 法をとった。

回叹後に含水量を測定し，侵入害虫を調べた．含水量

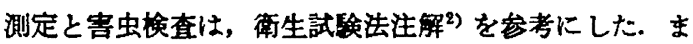
た，侵入害虫類を調べる時は，(1のねじ込みぶた式密閉 かんと(2)のポリェチレンふた密閉かんは, 全量 $50 \mathrm{~g}$ を 40 50 $0^{\circ}$ の温晹に溶かし，少量の中性洗郕を入れてかく はんし，セジメントテスターでろ過して，実体影改鏡下 で害虫類を採取した. (3)のふたのせかんと(4)の $1 / 4$ あけ かんは，表面から $1 \mathrm{~cm}$ をとり，同じ方法でろ過した。

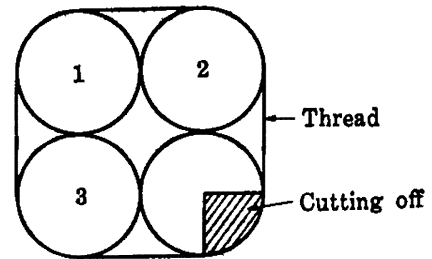

Fig. 2. Four types of milk powder cans were tied by a thread.

\section{結果および考蕒}

測定した含水量と侵入客虫の種頪数との间の相関を調 べた成栱は Table 3 のとお゙りである. 使用したデータ は，ふたのせかん（3）と1/4 あけかん（4) だけであ ろ.

(1) と (2) の密閌かんは害虫が 侵入しにくいので除外し た. 1 かん中の害虫の種類数は $0 \sim 5$ 種類であり, 含水 量は3 10\%であった．含水贯の低いものでは害虫の種 類数が少く，高いものでは種類は增えるという傾向を示 している.ふふふたのせかんと $1 / 4$ あけかんの合計 180 かん の個々の含水量 $(\%)$ と，1 かん中の種類数の相関保教を 計算すると， $r=0.485$ となった. 自由度 $d f=150,1 \%$ 危険率の相関係数 $r=0.208$ より大きく，有意の相関が 認められた。これは，育粉かんを置く場所が湿っている と，侵入してくる害虫の種類数が多くなることを意味し ている.

Table 4 は，侵入害虫の種類とそのかん数とを表した むのである. 侵入害虫は昆蠳 9 種，ダ二類11種の計 20 種であった．昆蝢で最も多かったものは，チャバネコ キブリ (Blattella germanica) で12かん，これに次ぐ ものは, コクヌストモドキ (Tribolium castaneum), ノシメマダラメイガ(Plodia interpunctella),トビイロ

Table 3. Relation between Water Content of Milk Powder and Number of Taxa of Invading Insects and Mites in Can

\begin{tabular}{c|c|c|c|c|c|c|c|c|c}
$\begin{array}{c}\text { Number of taxa } \\
\text { of invading in- } \\
\text { sects and mites } \\
\text { in can }\end{array}$ & \multicolumn{2}{|c|}{ Percentage of water content } \\
\hline & $3.0-3.9$ & $4.0-4.9$ & $5.0-5.9$ & $6.0-6.9$ & $7.0-7.9$ & $8.0-8.9$ & $9.0-9.9$ & 10 & Total \\
\hline 0 & 3 & 20 & 46 & 20 & 4 & & & 1 & 94 \\
1 & 1 & 5 & 22 & 25 & 12 & 2 & 1 & & 68 \\
2 & & 1 & 3 & 7 & & 1 & 1 & & 13 \\
3 & & & & 1 & & & 2 & & 3 \\
4 & & & & & & & 1 & & 1 \\
5 & & & & & & 1 & & & 1 \\
\hline Total* & 4 & 26 & 71 & 53 & 16 & 4 & 5 & 1 & 180
\end{tabular}

* Total of cans covered loosely by polyethylene-caps without being closed and cans closed by caps of which one-fourth parts were cut off. 
Table 4. Number of Milk Powder Cans Invaded by Insects and Mites

\begin{tabular}{|c|c|c|c|c|c|c|c|c|}
\hline \multirow{3}{*}{ Taxa of invading insects and mites } & \multicolumn{7}{|c|}{ Types of milk cans } & \multirow{3}{*}{ Total } \\
\hline & No. 1 & \multicolumn{2}{|c|}{ No. 2} & \multicolumn{2}{|c|}{ No. 3} & \multicolumn{2}{|c|}{ No. 4} & \\
\hline & $\mathrm{D} \mathrm{S}$ & $\mathrm{D}$ & $\mathbf{s}$ & $\mathrm{D}$ & $\mathbf{S}$ & $\mathrm{D}$ & $\mathbf{S}$ & \\
\hline Blattella germanica & & & & $\mathbf{5}$ & 1 & 5 & 1 & 12 \\
\hline Periplaneta japonica & & & & & & 1 & & 1 \\
\hline Liposcelidae & & & & & 1 & & 1 & 2 \\
\hline Ectopsocus sp. & & & & & 1 & & & 1 \\
\hline Tribolium castaneum & 1 & & & & 1 & & 1 & 3 \\
\hline Anobiidae & & & & 1 & & & & 1 \\
\hline Plodia interpunctella & 1 & & & 1 & & 1 & & 3 \\
\hline Scatopsidae & & & & & & 1 & & 1 \\
\hline Lasius niger & & & & 2 & & & 1 & 3 \\
\hline ?Melichares (Blattisocius) dentriticus & 2 & & & & 2 & & 4 & 8 \\
\hline Melichares (Blattisocius) keegani & & & & & & 1 & & 1 \\
\hline Laelapidae & & & & & 2 & & & 2 \\
\hline ?Leiodinychus sp. & 1 & & & & 2 & & 1 & 4 \\
\hline Tydeidae ?Lorryia sp. & 1 & & & & & & & 1 \\
\hline Cheyletus sp. & & & & 1 & & & & 1 \\
\hline Cheyletinae & & & & & & & 1 & 1 \\
\hline Tyrophagus putrescentiae & 613 & & 5 & 13 & 21 & & 20 & 92 \\
\hline Lardoglyphus konoi & 1 & & & & 1 & & 1 & 3 \\
\hline Suidasia nesbitti & & & & 1 & & 1 & & 2 \\
\hline Dermatophagoides farinae & & & & & & 1 & & 1 \\
\hline Total & $7 \quad 19$ & & 5 & 24 & 32 & 25 & 31 & 143 \\
\hline
\end{tabular}

No. 1: Cans were closed by metal screw caps.

No. 2: Cans were closed by polyethylene-caps.

No. 3: Cans were loosely covered by polyethylene-caps without being closed and fixed by vinyl tapes on both sides.

No. 4: Cans were closed by caps of which one-fourth parts were cut off.

D: Downtown S: Suburbs

ケフリ (Lasius niger) (同定は植物防疫，1966による)

でそれぞれ3かんずつであった. また，ダ二類では， ケナガコナダ= (Tyrophagus putrescentiae) が 92 か んで取も多く, ?フッウマヨイダ= (?Melichares (Blattisocius) dentriticus) が 8 かんで 2 番目に多かった。 (1)と(2)の 2 種類の密閉かんに侵入した害虫は，ダ二類が 多く、屁虫類はコクヌストモドキ幼虫（同定は日本奻虫 困籃，1961Kよる）とノシメマダラメイガ奻虫であり， コクヌストモドキ幼虫は生存していた. 侵入害虫の生死 については，温湯や中性洗㓣を入れてかくはんしたため 確実なデータはとれなかったが，密閉かんに侵入したダ 二類は死んでいたもるが多く，ふたのせかんや $1 / 4$ あけ かんに入った害虫類は，生さていたと思われるむのが多 かった. 密閉かんでダ二類が多く死んでいたのは，かん 内湿度が低かったからであろら。
密閉かんやふたのせかん，1/4 あけかんの害虫侵入か ん数を調べると，密閉かんの方がふたのせかんや1/4 あ けかんよりは少なく，また，密閉かんについては，ポリ エチレンふた密閉かんの方がねじ込みぶたの密閉かんよ りもはるかに少なく，㧤計上の有意差が明らかに認めら れた。 やはり，ボリェチレンぶた密閉かんの方がすき間 が少ないせいか，侵入しにくいようである.ボリェチレ ンふた密閉かんに唚入したものはケナガコナダニだけで あるが，その最大のむのは $500 \mu \times 280 \mu$ であり，ねじ込 みふた密閉かんに侵入した取大のむのはコクヌストモド キ幼虫で, $1,220 \mu \times 220 \mu$ であった.

ポリエチレンふたの密閉かんKケナガコナダ二が侵入 したものは 5 かんで，侵入数は，それぞれ $4 ， 2 ， 2 ，$ 1，1匹であった.これらの侵入かんについて，同じ場 所に設㢄したその他の 3 かんの传入数を調べると，多い 
ものは 1,000 匹以上いるし，少ないものは 5 匹であっ た.このよ5に，その他の3かんに侵入したヶナガコナ ダニ数に変動があるのは，ふたによってはすき間の変動 があるためか，設置場所が原因なのか恃，はっきりしな い。ボリエチレンふた密閉かんにケナガニナダ二が侵入 した家庭と侵入しない家庭についての設置場所や隣接食 品類を調へたが，特改的な羑はみられなかった。

都心群, 都下群別, 団地, 一户建, 商店別, 設尿時期 別のそれぞれについての差を，害虫侵入かん数で調へた が,いずれも $1 \%$ \%ベルでは有意差はなかった. 商店に おける害虫侵入かん数は団地, 一戸建に比へて, $5 \%$ ヘルで有意差があったが，これは，この調査に対して神 释質になりすぎていた商店があったためではなかったか 之思5.

括

昭和 49 年 $6 \sim 11$ 月にかけて，4 種類の育粉かん（ね じ込みぶたの密閉かん，ポリェチレンふたの密閉かん， ふたを简単に上にのせたかん，らたを $1 / 4$ あけたかん） を, 東京都心と都下の団地, 一戸建, 商店それぞれ 5 軒 計30幹の家庭に 2 週间淤き，育粉かんに侵入する害虫に 関する調查を行い次の結果を得た。

（1）含水量と侵入害虫の種類数の間には相関があ り，育粉かんを貪いた場所の湿気が多い場合には侵入害
虫の種類も多い。

（2）ねじ込みぶたの嘧閉かんよりもボリエチレンふ たの密閉かんの方がはるかに害葠入の頻度が少なかっ た.

（3）都心，都下別，団地，一戸建，商店別，設置時 期別の害虫侵入率には有意の差は認められなかった。

本研究は日本食品衙生学会の援助により行ったもので あり、ここに感㱛の意を表する．有益な助言を賜わった 宮䲨弘衛博士, 助言と㙝力を賜わった都立衛生研究所野 牛弘環境保健部長および調查に劦力下さった当研究所職 員各位，保健所食品衙生橦各位に厚く感謝寸る。

文嗝

1）長谷川 恩, 服部晆作, 神木寻一：北街試所報， 21, 60 (1971).

2）浮田忠之進他：日本菜学会編，金原出版 “街生漹 跨法注解” p. 53 (1973).

3）久保田政雄，近藤正㯕，今井弘民：植物防莈， 20(11), (1966).

4）佐々 学, 内田 亨: ダ二類, (1970) 東大出版 会.

5）河田 党他：日本幼虫园，（1961）北隆馆.

6）朝比奈正二郎他：衛生㲜物検查指針, (1971) 日 本環境衛生センター。 